\title{
Histological Features of the Renal Arteries in Indian Goat (Capra hircus)
}

\author{
B. Padmasri ${ }^{*}$, D. Pramod Kumar ${ }^{1}$, G. Purushotham ${ }^{1}$ and K.B.P. Raghavender ${ }^{2}$ \\ ${ }^{1}$ Department of Veterinary Anatomy, ${ }^{2}$ Department of Veterinary Surgery and Radiology, \\ CVSc, Hyd., Telangana, India \\ *Corresponding author
}

\section{A B S T R A C T}

\begin{tabular}{|l|}
\hline Ke y w o r d s \\
Renal artery, Goat \\
\hline Article Info \\
\hline Accepted: \\
20 March 2018 \\
Available Online: \\
10 April 2018 \\
\hline
\end{tabular}

\section{Introduction}

Arteries comprise three distinct layers viz., tunica intima, media and adventitia whose structural proportion varied with the size and function of the particular artery.

Tunica intima of muscular artery consists of elongated flattened endothelial cells resting on areolar connective tissue. Increased amount of smooth muscle fibers with internal and external elastic membranes are seen in tunica media.

Tunica adventitia comprises collagen and elastic fibers predominantly and vasa vasorum. Small nutrient arteries and veins occur in the wall of larger vessels (Aughey and Frey 2001 in mammals and Eurell et al., 2006 in domestic animals).

Fewer strands of elastic fibers are seen in tunica media. Inner and outer layer of smooth muscle are arranged longitudinally and circularly in renal artery. Longitudinally oriented smooth muscle is present in the tunica intima between the endothelium and internal elastic membrane (Bacha and Bacha, 2000 in dogs and cats respectively).

Transition from elastic to muscular arteries may either be gradual or abrupt and the site of transitional zone for each vessel varied among species and individual animals (Eurell et al., 2006 in domestic animals) and in dogs by Nowrozani and Asmarian (2014). 


\section{Materials and Methods}

Renal artery samples were collected from twelve adult apparently healthy goats along with kidneys, part of aorta, venacava and ureter. Tissue samples of right and left renal arteries of goats were taken from all specimens at three places of the main trunk viz., one closer to the aortic origin, other in the middle of its course and the third closer to the hilus of kidney. Samples were preserved in $10 \%$ NBF solution and later were processed for routine paraffin method (Singh and Sulochana, 1997). About 4-5 $\mu$ m thick paraffin sections were stained for routine $\mathrm{H} \& \mathrm{E}$ and other special staining techniques such as Mallory's triple stain method (Singh and Sulochana, 1997) and Verhoeff's stain for demonstration of elastic fibres (Culling 1974).

\section{Results and Discussion}

In the present investigation all three renal arterial segments taken from proximal, middle and distal parts of main renal artery in goats on both sides revealed typical microscopic features of a muscular artery. The arterial wall consisted of three layers within outwards viz., tunica intima, tunica media and tunica adventitia respectively (Figs. 1 and 2). In all of the above specimens the tunica media consisted of relatively thick coat of smooth muscle cells mostly arranged in circular fashion, which is in concurrence with the description of muscular arteries by several authors (Vodenicharov and Cirnuchanov, 1995 in domestic swine; Dellmann and Eurell, 1998 in domestic animals; Alessandro et al., 2006 in swine; Gholami et al., 2007 in sheep; Parchami et al., 2009 in sheep and goat; Norouzani et al., 2008 in cats, Nowrozani, 2010 and 2011; Nowrozani et al., 2012 and Nowrozani and Asmarian, 2014 in dogs). Content of elastic fibres in tunica media was negligible in the goat and pig renal arteries studied.
The intima of renal artery in goats was lined by single layer of endothelial cells attached closely to underlying connective tissue and limited by wavy internal elastic membrane (IEM). Undulations of IEM resulted in its protrusion into smooth muscle enriched tunica media (Fig. 3), thin continuous wavy line above which negligible amounts of subendothelial connective tissue was seen. These observations are in agreement with the findings of Vaish et al., (2003) in adult goats, Alessandro et al., (2006) in pigs and Gholami and Haghighat (2007) in post natal sheep. They further mentioned that sub-endothelial connective tissue was minimal or almost absent in these animals.

In three segments sub-endothelial connective tissue of renal artery was quite thick over a translucent IEM and comprised few collagen and elastic fibres between which some smooth muscle nuclei were observed (Fig. 4), IEM was moderately thick solid wavy structure limiting tunica intima and was continuous in all three segments in goats (Fig. 5) and they were filled up with packed collagen fibres and few smooth muscle cells.

Similar 'tufts' like structure was reported in domestic swine by Vodenicharov and Cirnuchanov (1995) who stated that internal elastic membrane was wrinkled with higher and wider curves between which longitudinally oriented smooth muscle cells forming 'tufts' were seen.

In the present study the tunica media was populated by more than 30 rows of smooth muscle cells oriented circularly. Its outer boundary was limited by fragmented thin wavy outer elastic membrane beyond which was the tunica media (Fig. 6). Similar reports were made in swine by Vodenicharov and Cirnuchanov (1995) and Alessandro et al., (2006) and Trautmann and Fiebiger (2002) in domestic animals. 
Fig.1 Photomicrograph of proximal segment of right renal artery of goat showing three layers namely tunica intima, media and adventitia

1 - Tunica intima

2 - Tunica media

3 - Tunica adventitia

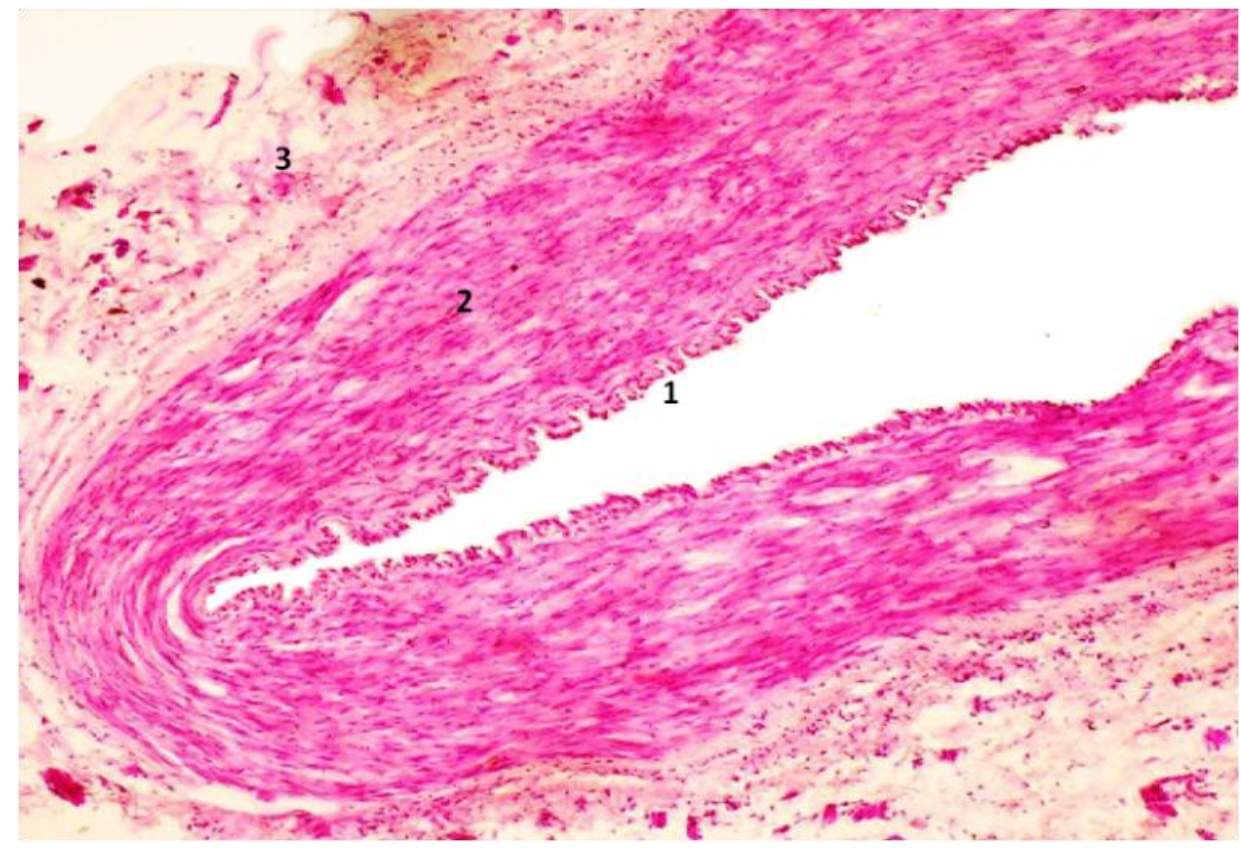

Fig.2 Photomicrograph of distal segment of left renal artery of goat showing three layers

(Mallorys triple stain $-10 x$ )

1 - Tunica intima

2 - Tunica media

3 - Tunica adventitia

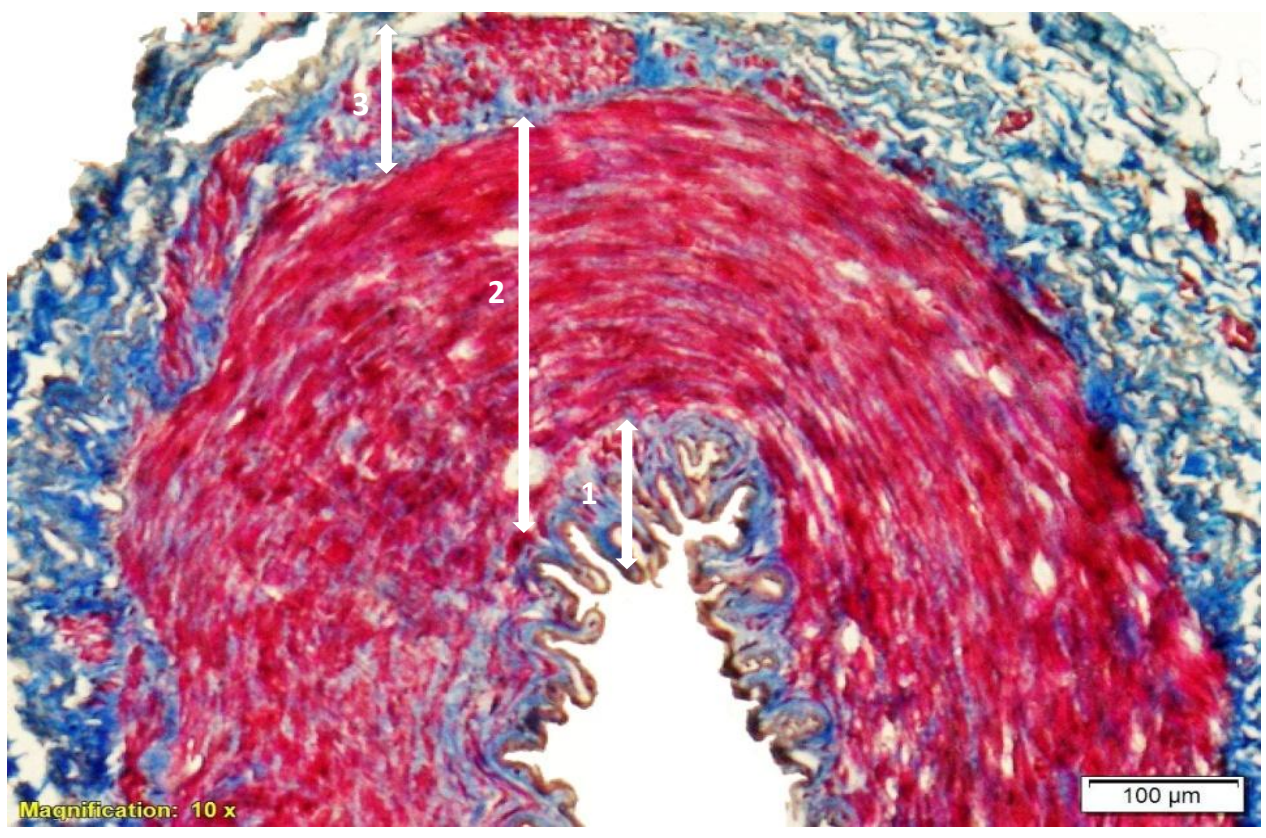


Fig.3 Photomicrograph of middle segment of Right renal artery of goat showing smooth muscle fibers in tunic media

$\rightarrow$ Internal elastic membrane

$(\mathrm{H} \& \mathrm{E}-16 \mathrm{x})$

Tm - Tunica media

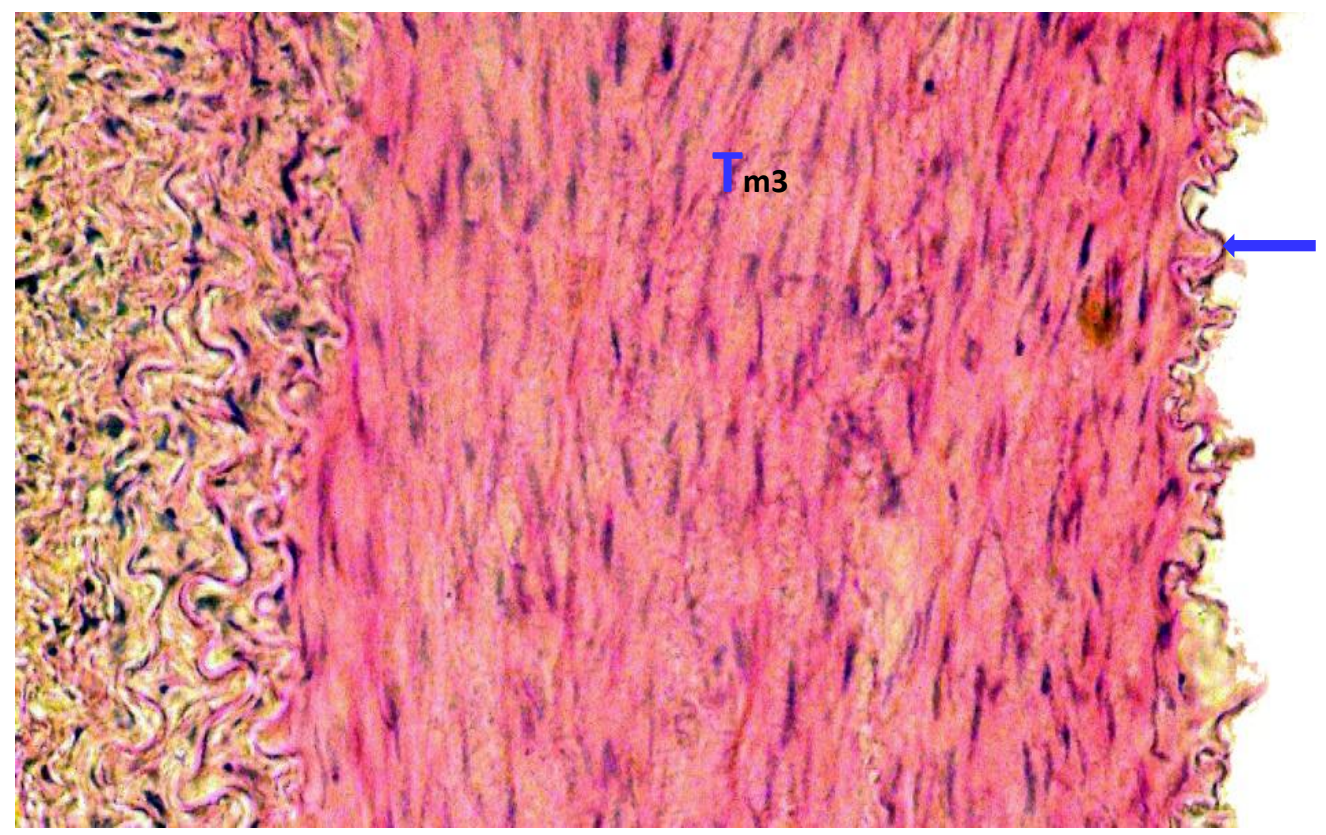

Fig.4 Photomicrograph of proximal segment of right renal artery of goat showing subendothelial connective tissue in tunica intima

1 - Endothelium

$(\mathrm{H} \& \mathrm{E}-40 \mathrm{x})$

2 - Subendothelial connective tissue

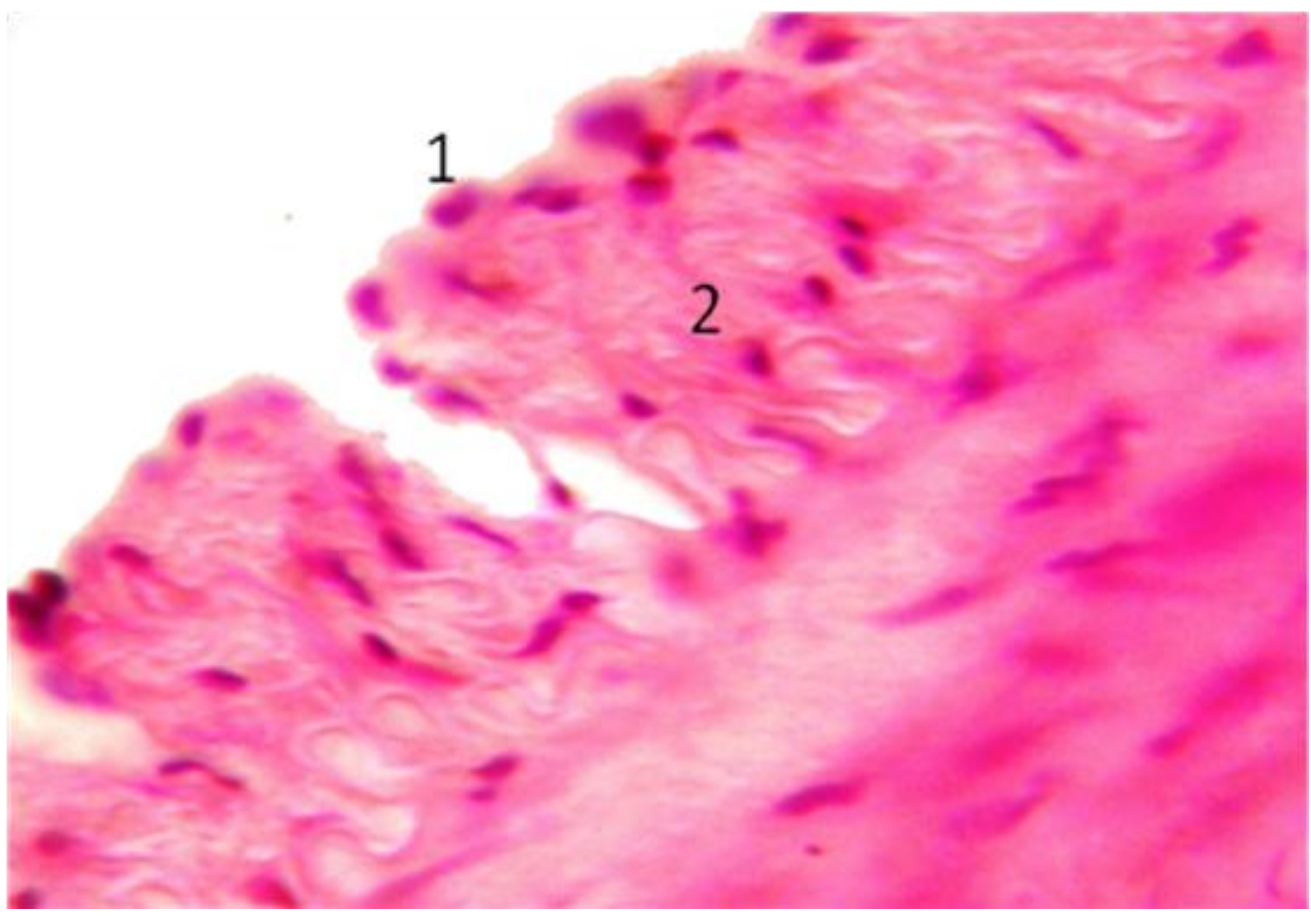


Fig.5 Photomicrograph of proximal segment of right renal artery of goat showing internal elastic membrane $(\rightarrow)$

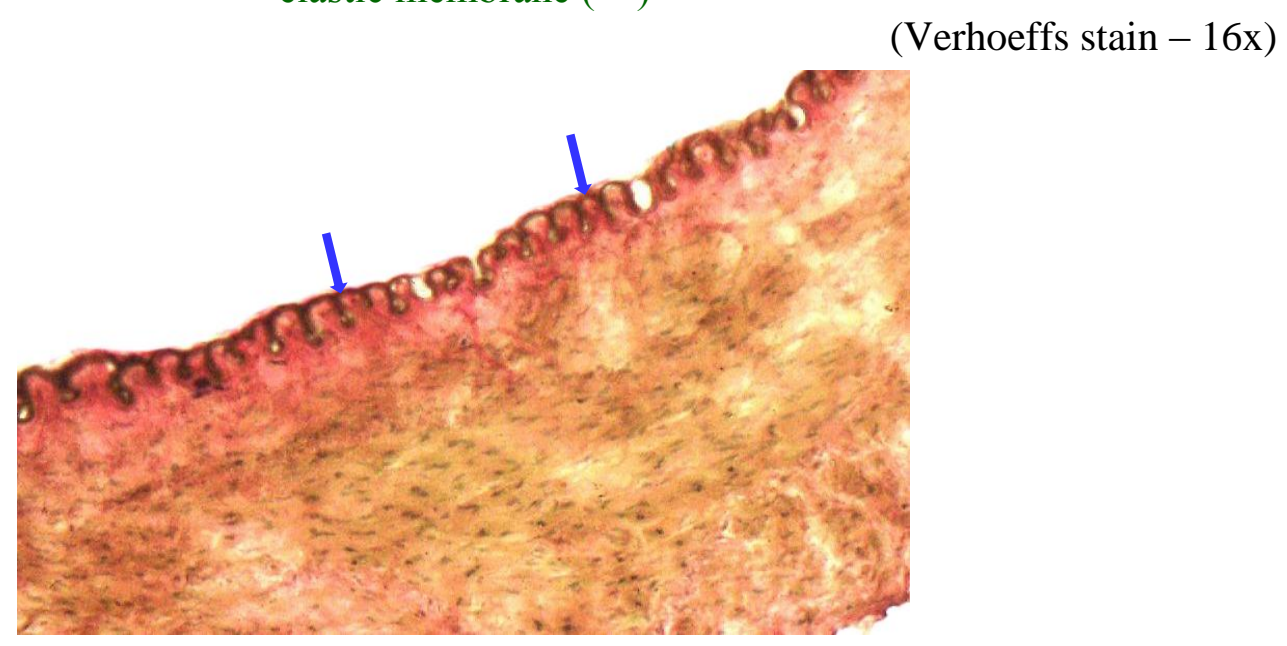

Fig.6 Photomicrograph of proximal segment of left renal artery of goat showing and elastic fibers $(\rightarrow)$ in tunica adventitia

$(\mathrm{H} \& \mathrm{E}-40 \mathrm{x})$

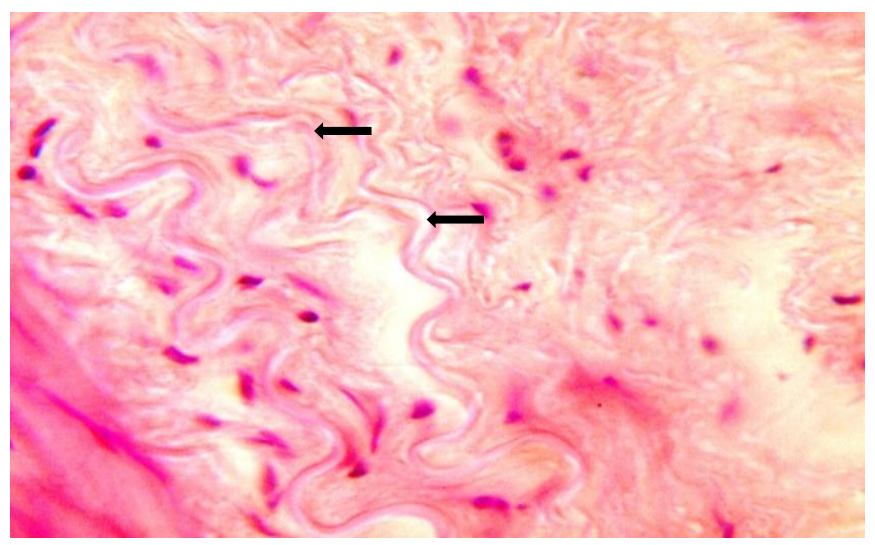

Fig.7 Photomicrograph of distal segment right renal artery of goat showing wavy elastic fibers $(\rightarrow)$ in tunica media

$(\mathrm{H} \& \mathrm{E}$ stain $-40 \mathrm{x})$

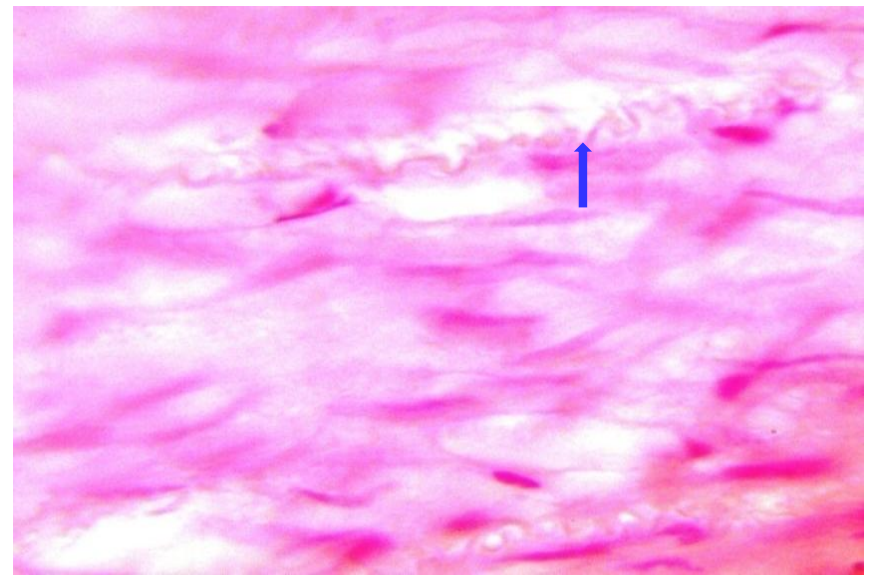


Fig.8 Photomicrograph of distal segment of right renal artery of goat showing outer connective tissue fibers enchroching the tunica media around the longitudinal bundles of smooth muscle fibers

*- Smooth muscle bundles

(Verhoeffs stain $-20 x)$ 1 - Outer elastic laminae

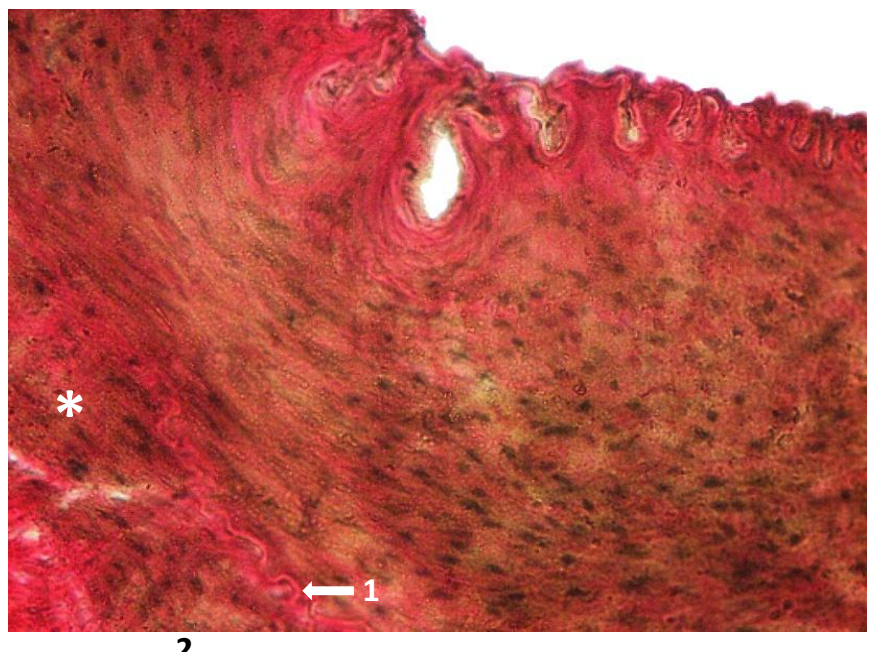

Immediately next to it were smooth wavy strands of elastic fibres located between connective tissue in adventitia (Fig. 6). Solitary wavy elastic fibres were seen in media on its outer side (Fig. 7). Outer part of tunica media comprised translucent lines which were seen enveloping inwards around longitudinal smooth muscle bundles (Fig. 8)

\section{References}

Alessandro D D Emanuele N Stefania M Amelio D Carlo B Andrea C and Francesco B 2006. Immediate structural changes of porcine renal arteries after angioplasty: A histological and morphometric study. Elsevier Ltd: 37: 255-261.

Aughey E, Frye F. Comparative veterinary histology. Manson Pub.; 2001.

Bacha Jr WJ, Bacha LM. Color atlas of veterinary histology. John Wiley \& Sons; 2012 Jan 19.

Culling, C. F. A. (1974). Handbook of histopathological and histochemical techniques. 3rd edition. Butterworths, London.

Dellmann HD and Eurell JA (1998). Textbook of veterinary histology. 4th. Edn., Philadelphia, Lea and Febiger. P: 450.

Eurell J A and Frappier (2006). Dellman's Textbook of Veterinary Histology. 6th Edition, Chp. 12. Blackwell Publishing Professional 2121 State Avenue, Ames, Iowa 50014, USA.

Gholami S. and Haghighat Jahromi, M. (2007). Histomorphologic study of the renal artery in post-natal life of sheep (Ovis aries), Iranian Journal of Veterinary Research University of Shiraz, Vol. 8, No. 4, Ser. No. 21.

Norouzani F R, Haghighat M, Gholami S. (2008). Morphometry of renal artery in two sexes of sheep at different ages. Journal of Animal and Veterinary Advances; 7: 889-91.

Nowrozani F R and Asmarian Sh. (2014). A microscopic study of the aortic branches structure in the Adult male dog, Journal 
of Physiology and Pharmacology Advances, 4(7): 396- 400.

Nowrozani F R. (2010). Investigation of Smooth Muscle Cells at the Junction of Renal Artery from Abdominal Aorta in Male Adult Dog. Journal of Animal and Veterinary Advances 9: 1242-1244.

Nowrozani R (2011). Structure of the orifice of the renal artery in the abdominal aorta in adult male dog. Iranian Journal of Veterinary Research, Shiraz University: 12(1): 34.

Parchami A, Dehkordi R A F and Derakhshan A (2009). Comparative histomorphometric study of the common carotid artery and its terminal branches in sheep and goat. Bulgarian Journal of Veterinary Medicine, 12(3): $165-170$.

Ramezani Nowrazani. (2012). A microscopic and stereological study of the renal artery transitional zone of the adult male dog. Turkish Journal of Veterinary and
Animal Sciences. 2012; 36(2): 115122TUBITAK doi: 10.3906/vet-1011580.

Singh U B and Sulochana S. (1997). Handbook of histological and histochemical Techniques. Premier publishing house, Hyderabad.

Trautman, A., and Fiebiger, J. (2002). Fundamentals of the histology of domestic animals (translated and revised 8th and 9th German editions by Habel, RE and Biberstein, EL).

Vaish R Parmer M L Malik M R and Taluja J S 2003. Ontogeny of axillary and femoral arteries of goats (Capra hircus). Indian Journal of Animal Sciences. 73: 498-500.

Vodenicharov A. and Cinuchanov P. (1995). Microscopical and ultrastructural studies of the renal artery in domestic swine. Anatomia Histologia Embryologia., 24: 237-240.

\section{How to cite this article:}

Padmasri, B., D. Pramod Kumar, G. Purushotham and Raghavender, K.B.P. 2018. Histological Features of the Renal Arteries in Indian Goat (Capra hircus). Int.J.Curr.Microbiol.App.Sci. 7(04): 2366-2372. doi: https://doi.org/10.20546/ijcmas.2018.704.271 